\title{
Meat Preservation with Addition of Kecombrang Leaves (Etlingera elatior) in Refrigerator Temperature
}

\author{
Citra Kusuma, Rusman*, Jamhari \\ Department of Livestock Product Technology, Faculty of Animal Husbandry, University of Gadjah Mada, Jl. Fauna 3 \\ Kampus UGM, Bulaksumur, Yogyakarta 55281, Indonesia. \\ *Corresponding author email: rusman@ugm.ac.id
}

\begin{abstract}
The purpose of this study was to determine the effect of kecombrang leaves (Etlingera elatior) on the physical, chemical and microbiological quality on meat stored at refrigerator temperatures. The research was conducted from June 2016 to August 2016 in the Laboratory of Meat Science and Technology Department of Product Technology, Faculty of Animal Science, Gadjah Mada University. This study used a completely randomized design (CRD) of $3 \times 3$ factorial ( 3 condition of kecombrang leaves, 3 storage time), each treatment was repeated 3 times, and the different means were tested by Duncan test. The results showed that the addition of kecombrang leaves and storage time significantly affected $(P<0.05)$ the total microbes in meat. Meat control $(8,00 \log \mathrm{cfu} / \mathrm{ml} \pm 0.48)$ and meat with the addition of kecombrang leaves powder (6.59 log $\mathrm{cfu} / \mathrm{ml} \pm 0.40)$ is more effective in suppressing total growing microbes compared to kecombrang leaves pasta ( $7.12 \mathrm{log} \mathrm{cfu} / \mathrm{ml} \pm 0.35$ ). Storage time decreased $\mathrm{pH}$ value and cooking loss. Kecombrang leaves condition and storage time did not affect water content, protein content, fat content and tenderness in beef.
\end{abstract}

Key words: kecombrang leaves, storage time, refrigerator, total microbes, antimicrobials and antioxidants.

Abstrak. Penelitian ini bertujuan untuk menentukan pengaruh daun kecombrang (Etlingera elatior) terhadap kualitas fisik, kimia dan mikrobiologi daging yang disimpan pada suhu lemari pendingin. Penelitian dilakukan dari Juni sampai Agustus 2016 di Laboratorium Ilmu dan Teknologi Daging, Departemen Teknologi Hasil Ternak, Fakultas Peternakan Universitas Gadjah Mada. Penelitian menggunakan Rancangan Acak Lengkap (RAL) dengan pola factorial $3 \times 3$ ( 3 kondisi daun kecombrang, 3 lama penyimpanan), masing-masing perlakuan diulang 3 kali, rataan perbedaan diuji dengan Uji Duncan. Hasil menunjukkan bahwa penambahan daun kecombrang dan lama penyimpanan berpengaruh nyata $(P<0,05)$ terhadap total mikroba dalam daging. Daging control $(8,00 \log \mathrm{cfu} / \mathrm{ml} \pm 0,48)$ dan daging dengan penambahan bubuk daun kecombrang $(6,59$ log $\mathrm{cfu} / \mathrm{ml} \pm 0,40)$ lebih efektif untuk mengurangi total pertumbuhan mikroba dibandingkan kecombrang dalam bentuk pasta $(7,12 \log \mathrm{cfu} / \mathrm{ml} \pm 0,35)$. Lama penyimpanan menurunkan nilai $\mathrm{pH}$ dan susut masak. Kondisi daun kecombrang dan lama penyimpanan tidak mempengaruhi kandungan air, protein, lemak dan keempukan daging.

Kata kunci : daun kecombrang, lama penyimpanan, refrigerator, total mikroba, antimikroba dan antioksidan

\section{Introduction}

Meat is a highly nutritious food so it is good for the growth and development of microbes. Declining meat quality may be indicated by changes in color, taste even decay, due to contaminating microbes and their growth on meat during storage. One effort to prevent this condition is preservation.

Meat preservation can apply addition of preservatives except some disrecommended ones such as borax and formaldehyde that can harm the body. Therefore, it is necessary to have an alternative of meat natural preservatives, for example kecombrang.
Kecombrang is one of the plants that contain antimicrobial and antioxidant agents. Phytochemical contents in the flowers, stems, rhizomes and leaves are alkaloids, saponins, tannins, phenolics, flavonoids, triterpenoids, steroids and glycosides that play an active role as antioxidant (Naufalin, 2005). The chemical components as potential antimicrobial agents in kecombrang are alkaloids, flavonoids, polyphenols, steroids, saponins and essential oils. Almost all parts of the plant contain polyphenols antimicrobial agent (Naufalin, 2013). The study was aimed to determine the effect of using the kecombrang leaves which 
have antimicrobial compound on the quality of beef stored at refrigerator temperatures.

\section{Materials and Methods}

\section{Materials}

The materials used in this study were beef, kecombrang leaves, label, paper, tissues, methylated spirits, cotton, PCA sterile, distilled water, and buffer. The tools that used in this study were petri dish, colony counter, needle loop, busen, incubator, measuring cups, autoclaves, tube rack, test tubes, erlenmeyer, bowl, cotton, aluminum foil, an analytical balance, pH meter, knives, blender, rope, paper, pots, stoves and stopwatch.

This study used a completely randomized design (CRD) of $3 \times 3$ factorial, with 3 treatments, namely, beef without kecombrang leaves $(K)$, beef soaked in kecombrang leaves pasta (S) and beef soaked in kecombrang leaves powder (B), and 3 storage times, namely, 0, 3 and 6 days. Each treatment was repeated 3 times, and the different means were tested by Duncan test.

\section{Methods}

Kecombrang leaves were washed, cut into pieces and ground to produce kecombrang leaves pasta. Whereas to produce kecombrang leaves powder, washed kecombrang leaves were cut into pieces, and oven-dried at $60^{\circ} \mathrm{C}$ for 24h. After drying, the leaves were ground into powder, then screened.

Sample preparation and storage of meat flesh. Kecombrang pasta and powder were diluted with $100 \mathrm{ml}$ aquadest. Five hundred grams of beef was incorporated in each solution including the control solution (distilled), kecombrang leaves pasta solution (7.5\%) and kecombrang leaves powder solution (7.5\%), the soaked for 2 hours. After being removed from the solution, meat was stored at refrigerator temperature in a pot and covered with plastic wrap. Meat qualities were observed on day 0, 3 and 6.

The measured variables included total microbes (Ray, 2001), antioxidant activity (Yen et al, 1995), peroxide value (Sudarmadji et al, 1997), water, protein and fat contents (Adrizal et al, 2006), pH (Fenita et al, 2009), cooking loss method by Bouton (Soeparno, 2015) and tenderness method by Warner-Bratzler (Soeparno, 2015).

\section{Results and Discussion}

\section{Total microbes}

The conditions of kecombrang leaves affected the total microbes of meat. The differences were due to higher water content in kecombrang pasta (80\%) than that in.

Table 1. Average of total meat microbes of kecombrang leaves condition and different storage time (log cfu / mg)

\begin{tabular}{lcccc}
\hline Leaves condition & \multicolumn{3}{c}{ Storage time (days) } & Mean \\
\cline { 2 - 4 } & 0 & 3 & 6 & \\
\hline Control & $6,45 \pm 0,66^{\mathrm{k}}$ & $8,36 \pm 0,07^{\mathrm{n}}$ & $9,20 \pm 0,71^{\mathrm{n}}$ & $8,00 \pm 0,48^{\mathrm{c}}$ \\
Pasta & $6,33 \pm 0,66^{\mathrm{k}}$ & $7,33 \pm 0,20^{\mathrm{1}}$ & $7,71 \pm 0,20^{\mathrm{m}}$ & $7,12 \pm 0.35^{\mathrm{b}}$ \\
Powder & $5,97 \pm 0,68^{\mathrm{k}}$ & $6,12 \pm 0,32^{\mathrm{k}}$ & $7,68 \pm 0,19^{\mathrm{m}}$ & $6.59 \pm 0,40^{\mathrm{a}}$ \\
Mean & $6,25 \pm 0,66^{\mathrm{p}}$ & $7,25 \pm 0,20^{\mathrm{q}}$ & $8,20 \pm 0,37^{\mathrm{r}}$ &
\end{tabular}

$a, b, c$ Different superscripts within column indicate significant differences $(P<0.05)$ $p, q, r$ Difference superscripts within row indicate significant differences $(P<0.05)$ 
kecombrang leaves powder. According to Rahayu et al . (2000), food product that has high water content and high water activity tends to increase the number and variety of microbes

Total microbes also increased over time. Total microbes on day 0,3 and 6 was $6.25,7.25$ and $8.20 \mathrm{log} \mathrm{cfu} / \mathrm{ml}$, respectively. The longer storage time, the lower meat quality would be lower be even decaying, because of complex compounds degradation as a result of autolysis process. Autolysis is the tissue and organ damage through chemical process by intracellular enzymes. Autolysis process occurs due to the effect of enzymes released by dead cells. Nucleoprotein in chromatin is firstly exposed after the cytoplasm, then cell walls will be damage so the tissue becomes soft or melts (Naufalin et al, 2010).

There was no interaction between kecombrang leaves conditions and storage time on total microbes. The lowest total microbe was found in meat with kecombrang leaves powder on day 0 and 3 (BO and B3) and that with kecombrang pasta was on day 0 (SO) and on meat control day 0 (KO). It was because antimicrobial compound in kecombrang leaves powder still showed high activity on day 0 and 3, so it could still suppress the growth of microbes because drying process of making kecombrang leaves powder reduced antimicrobial compound in kecombrang leaves such as flavonoid on day 3. The drying process could decrease flavonoid levels in antimicrobial compounds by 15 to $78 \%$ (Lusivera, 2000).

The highest total microbes was in beef on day 6 (K6) because of lacking antimicrobial activity. Meat with kecombrang leaves pasta on day 6 (S6) also had high total microbes $7.71 \mathrm{log}$ $\mathrm{cfu} / \mathrm{ml}$. The antimicrobial on the leaves did not work optimally because of low supplemental kecombrang and moisture content allows more microbes to grow on meat. Faradisa (2008) reported that antibacterial compounds in the larger plant is directly proportional to the level of concentration, therefore the greater the concentration, the greater the inhibition zone is formed.

\section{The antioxidant activity}

Table 2. DPPH number of the condition of kecombrang leaves pasta and powder (\%)

\begin{tabular}{lcc}
\hline Type preservation & Pasta & Powder \\
\hline $\begin{array}{l}\text { The antioxidant } \\
\text { activity (percent) }\end{array}$ & 61.30 & 52.80 \\
\hline
\end{tabular}

The results showed that antioxidant activity of kecombrang leaves could prevent free radicals. Antioxidant activity of kecombrang leaves pasta was higher (61.30\%) than that of kecombrang leaves powder (52.80\%) due to the drying process in kecombrang leaves powder. Estiasih et al. (2009) reported that drying time prolonged contact with hot material. Longer drying time would decrease antioxidant activity. Overall, all the meat samples in powder has a lower antioxidant activity than that of kecombrang leaves pasta (Wahyuningdiani et al, 2015).

\section{Peroxide value}

The results showed that kecombrang leaves condition significantly affected peroxide value. The lowest peroxide value $(0.11 \mathrm{mg} / \mathrm{kg})$, was on the meat with kecombrang leaves pasta, followed by $0,14 \mathrm{mg} / \mathrm{kg}$ in control meat, and the highest was $0,23 \mathrm{mg} / \mathrm{kg}$ on kecombrang leaves powder. It may be that antioxidant compounds of kecombrang leaves pasta is more effective than kecombrang leaves powder. Ngadiarti et al (2013) found that one method to anticipate oxidation was the use of preservatives containing antioxidants or addition of certain nutrients such as vitamin $E$ to inhibit fat oxidation.

The highest result was the meat with kecombrang leaves powder because the drying process damaged the antioxidant compound of the leaves. Kecombrang leaves powder that was dried at $60^{\circ} \mathrm{C}$ for $24 \mathrm{~h}$ showed damage in 
chemical components in the leaves. According to the Wahyunindiani et al (2015), the highest and lowest antioxidant activity of soursop leaves was reached at $50^{\circ} \mathrm{C}$ and $60^{\circ} \mathrm{C}$ drying temperature, respectively. Lusivera (2002) this thermal process led to the decline in total flavonoids level by 155 to $78 \%$. The results showed that the peroxide value with kecombrang condition was still within normal range or 5 to $5.92 \mathrm{mg} / \mathrm{kg}$ according to SNI (014473-1998).

The duration of storage also affected peroxide value. Storage time increased peroxide value of meat. Peroxide value on 0,3 and 6 days was 0,$08 ; 0,16$ and $0,24 \mathrm{mg} / \mathrm{kg}$, respectively. The increase was due to the amount of oxygen contact with oil/fat. High level of oxygen leads to the production of secondary compounds which accelerates the oxidation process. The peroxide compound was able to oxidize fatty acid molecules removing two hydrogen atoms form double bonds of new and further reduced to form an oxide (Montesqrit et al . 2013).

There was an interaction between kecombrang leaves conditions and storage time on peroxide value of meat. The lowest peroxide value was on meat with kecombrang leaves pasta day 0 (SO) and control meat (KO). The highest peroxide value $(0.34 \mathrm{mg} / \mathrm{kg})$ is observed in meat with kecombrang leaves on day 6 (B6). This study indicated that kecombrang leaves pasta could prevent oxidation more optimally than kecombrang leaves powder.

It is anticipated by the provision of kecombrang leaves pasta that the antioxidant compound still worked effective, so it could suppress oxidation of meat compared to kecombrang leaves powder that has undergone a heating process that damaged antioxidant. The damaged antioxidant compounds would oxidize beef faster, so if they are retained will not provide significant impact in suppressing oxidation.

According to Suhairi (2015), the drying process resulted in higher product peroxide value than that without drying. The higher the peroxide value of a food, the higher the fat damage due to food processing especially heating. It is This is consistent with research that reported peroxide value of kecombrang leaves powder of supreme beef.

\section{Water content}

The results showed that the condition leaves kecombrang had no affected on water content. The average of water content of control meet, kecombrang leaves pasta and kecombrang leaves powder was 7,44; 73,90 and 73,70\%, respectively. This was due to kecombrang leaves did not have humectant properties, in which attracted moisture content in a material. According to Hiariey et al. research (2015), one

Table 3. Average meat peroxide value of kecombrang leaves condition and different storage time $(\mathrm{mg} / \mathrm{kg})$.

\begin{tabular}{lcccc}
\hline & \multicolumn{3}{c}{ Storage time (days) } & \multirow{2}{*}{ Mean } \\
\cline { 2 - 4 } Leaves conditions & 0 & 3 & 6 & $0.14 \pm 0.02^{\mathrm{b}}$ \\
Fresh & $0.07 \pm 0.03^{\mathrm{k}}$ & $0.15 \pm 0.01^{\mathrm{m}}$ & $0.21 \pm 0.02^{\mathrm{n}}$ & $0.11 \pm 0.01^{\mathrm{a}}$ \\
Powder & $0.05 \pm 0.01^{\mathrm{k}}$ & $0.11 \pm 0.01^{1}$ & $0.17 \pm 0.01^{\mathrm{m}}$ & $0.23 \pm 0.02^{\mathrm{c}}$ \\
Mean & $0.11 \pm 0.01^{1}$ & $0.23 \pm 0.02^{\mathrm{n}}$ & $0.34 \pm 0.02^{\circ}$ & \\
\hline
\end{tabular}

a b c Different superscripts within column indicate significant differences $(P<0.05)$.

$p, q, r$ Different superscripts within row indicate significant differences $(P<0.05)$. 
Table 4. Average meat water content of kecombrang leaves condition and different storage time (\%).

\begin{tabular}{lcccc}
\hline \multirow{2}{*}{ Leaves conditions } & \multicolumn{3}{c}{ Storage time (days) } & \multirow{2}{*}{ Mean ${ }^{\text {ns }}$} \\
\cline { 2 - 4 } Control & 0 & 3 & 6 & $73.44 \pm 0.55$ \\
Pasta & $73.00 \pm 1.14$ & $73.97 \pm 0.33$ & $73.34 \pm 0.18$ & $73.90 \pm 0.39$ \\
Powder & $73.66 \pm 0.25$ & $74.17 \pm 0.52$ & $73.86 \pm 0.39$ & $73.70 \pm 1.05$ \\
Mean & $74.53 \pm 1.18$ & $73.55 \pm 1.08$ & $73.00 \pm 0.88$ & \\
\hline
\end{tabular}

ns Non-significant

way to decrease the water activity that was addition of additives which have a high water holding capacity (humectant).

The results showed that the storage time did not significantly effected on meat water content. The average water content on meat ranged from 73,40 to $73,90 \%$. This is due the storage of meat was done by keeping into plastic to prevent contamination from the outside like a dew water in the refrigerator. Packaging with plastic led to keep water not to enter to the product. Vergiyana et al. (2014) said that, the water content did not change during storage due to meat kept in a refrigerator and packed in plastic. Brody (2000) states that, the product should be protected to control the water content. Most of the dried products were hygroscopic, absorb water, wet product otherwise prone to loss of moisture.

\section{The protein content}

The results showed that the leaves condition had not affect on meat protein. This was due to kecombrang leaves was more applied in a antimicrobial and antioxidant activity than change the chemical compound in meat. Naufalin (2005) stated that, protein content of kecombrang ranging from 1 to $1.3 \mathrm{~g}$ per $100 \mathrm{~g}$. Because of low protein content, it caused protein content had no significantly effect. The protein content of meat control, meat with kecombrang leaves pasta and meat with kecombrang leaves power was 19,49; 19,27 and $18,73 \%$, respectively. The results were in association with the average protein content on meat 16 to $22 \%$ (Soeparno, 2015).

The results showed that storage time also did not affect on protein content. This was due to water content of meat during storage did not change, so it did not also affect the protein content of meat. This result was in line with Vergiyana et al. (2014) research that, the water content did not change during storage time resulted in non significant protein levels. Ismail et al (2011) also stated that, increase of a component in a material resulting in a decrease in other components. Arbele et al (2001) states that, the higher the water content would lead to be lower the fat content. Water level was positively correlated with the level of protein so that protein content had also negative correlation with fat content.

Table 5. Average meat protein content of kecombrang leaves condition and different storage time (\%).

\begin{tabular}{lcccc}
\hline Leaves condition & \multicolumn{3}{c}{ Storage time (days) } & \multirow{2}{*}{ Mean $^{\text {ns }}$} \\
\cline { 2 - 4 } & 0 & 3 & 6 & $19.49 \pm 0.32$ \\
\hline Control & $19.10 \pm 0.75$ & $19.53 \pm 0.15$ & $19.83 \pm 0.06$ & $19.27 \pm 0.23$ \\
Pasta & $18.80 \pm 0.17$ & $19.20 \pm 0.26$ & $19.80 \pm 0.26$ & $18.73 \pm 0.78$ \\
Powder & $18.77 \pm 0.76$ & $18.50 \pm 0.87$ & $18.90 \pm 0.72$ & $19.51 \pm 0.35$ \\
Mean & $18.90 \pm 0.56$ & $19.08 \pm 0.43$ &
\end{tabular}

ns Non-significant 


\section{Fat content}

The result showed that kecombrang leaves condition did not significantly affect fat content. The average of fat content of meat ranged from 4,14 to $4,88 \%$. This was due to antioxidant compounds of kecombrang leaves prevented oxidation on fat, and kept the quality of the fat. Khine et al (2011) states that increase of antioxidant compound could prevent more oxidation in fat. With the increasing of power resistor, the antioxidant activity also increased to inhibit the oxidation of fat. The average fat content on meat control, meat with kecombrang leaves pasta and meat with kecombrang leaves powder was 4.88, 4.14 and $4.62 \%$, respectively. Fat content in this study $(4,14$ to $4,88 \%)$ was within the standard from 1.5 to $13 \%$ ( Soeparno, 2015)

The storage time up to 6 days at refrigerator also showed no significant differences, where the average fat content ranged from 4,46 to $4,69 \%$. It was because the meat was packed in plastic and stored in the refrigerator, so it prevented chemical changes, including fat. Vergiyana et al . (2014) reported that sausages stored in a refrigerator temperatures showed no different meat fat content. Oxygen in the air reacted with most food products (Brody, 2000). By creating a barrier between the air and food products, packaging could inhibit the fat oxidation of fat. Fat is an important nutrient component, thereforew if the liquid fat was removed from the mass product and the storage room for a long (Soekarto, 1990) time at room temperature $\left( \pm 28^{\circ} \mathrm{C}\right)$ there would be irregular degradation of resulting product properties.

\section{The $\mathrm{pH}$ value}

The results showed that kecombrang leaves condition did not significantly affect $\mathrm{pH}$. The average $\mathrm{pH}$ ranged from 5,70 to 5,71 due to minimum kecombrang leaves level and released only little $\mathrm{H}+$ ions. $\mathrm{pH}$ value of kecombrang leaves condition in this study ranged from 3.8 to 4.2 .

According to Naufalin et al (2010), the higher concentration of kecombrang flower pasta, the more $\mathrm{H}+$ ions released by the organic acids from the kecombrang flower pasta. However, lacking kecombrang, did not affect the decreasing $\mathrm{pH}$ value of meat.

Table 6. Average meat fat content of kecombrang leaves condition and different storage time (\%).

\begin{tabular}{lcccc}
\hline Leaves conditions & \multicolumn{3}{c}{ Storage time (days) } & \multirow{2}{*}{ Mean $^{\text {ns }}$} \\
\cline { 2 - 4 } & 0 & 3 & 6 & \\
\hline Control & $5.80 \pm 1.65$ & $4.40 \pm 0.69$ & $4.43 \pm 0.40$ & $4.88 \pm 0.91$ \\
Pasta & $4.67 \pm 0.12$ & $3.77 \pm 0.55$ & $3.97 \pm 0.65$ & $4.14 \pm 0.44$ \\
Powder & $3.60 \pm 1.77$ & $5.30 \pm 1.25$ & $4.97 \pm 1.25$ & $4.62 \pm 1.42$ \\
Mean & $4.69 \pm 1.18$ & $4.49 \pm 0.83$ & $4.46 \pm 0.77$ & \\
\hline
\end{tabular}

ns Non-significant

Table 7. Average meat $\mathrm{pH}$ value of kecombrang leaves condition and different storage time.

\begin{tabular}{lcccc}
\hline Leaves condition & \multicolumn{3}{c}{ Storage time (days) } & \multirow{2}{*}{ Mean $^{\text {ns }}$} \\
\cline { 2 - 4 } & 0 & 3 & 6 & $5.71 \pm 2.62$ \\
Control & $5.90 \pm 1.00$ & $5.83 \pm 5.77$ & $5.40 \pm 1.09$ & $5.70 \pm 3.85$ \\
Pasta & $5.87 \pm 5.77$ & $5.80 \pm 0.00$ & $5.43 \pm 5.77$ & $5.70 \pm 0.73$ \\
Powder & $5.90 \pm 1.09$ & $5.80 \pm 0.00$ & $5.40 \pm 1.09$ & \\
Mean & $5.89 \pm 2.62^{\mathrm{p}}$ & $5.81 \pm 1.92^{\mathrm{q}}$ & $5.41 \pm 2.54^{\mathrm{r}}$ & \\
\hline
\end{tabular}

$\overline{p, q}, \mathbf{r}$ Different superscripts within row indicate significant differences $(P<0.05)$.

${ }^{n s}$ Non-significant 
The results showed that storage time significantly affected $\mathrm{pH}$ value of meat. Pearson (1987) states that low temperature can inhibit decrease of $\mathrm{pH}$ value on the bacon. This is obvious from the destruction rate of control meat inhibited by low temperatures that was a decrease in $\mathrm{pH}$ between $\mathrm{pH} 5.9$ inhibited up to 5.4 .

The average $\mathrm{pH}$ values on 0 days of storage tended to be higher when compared with storage time the next day. This was due to the activity of natural lactic acid bacteria in meat that was still relatively low, causing the small number of lactic acid formed in the meat. After 3 days of storage, the $\mathrm{pH}$ of meat tended to decline as a metabolic activity of lactic acid bacteria increase with duration of storage. The lactic acid bacteria would break down carbohydrates into lactic acid, an organic acid. Storage time would cause the accumulation of lactic acid produced by lactic acid bacteria so that more and more organic acid compounds contained in meat decreased of meat $\mathrm{pH}$. This was in line with Pestariati (2008) that glycogen metabolism produced lactic acid and resulted in the $\mathrm{pH}$ value decrease. Setyorini et al. (2010) added that, lactic acid bacteria was capable to produce lactic acid through metabolism of carbohydrates and caused to lower the $\mathrm{pH}$. Besides, the presence of lactic acid and low pH would inhibit the growth of microbial pathogens.

\section{Cooking losses}

The results showed that kecombrang leaves condition did not significantly affect cooking loss in meat. It was because the protein content result in this research had not been change, so the cooking losses also were still the same. Protein content affected cooking loss in meat because according to Soeparno (2015) meat protein plays an important role in the binding of the broth, high protein content in meat increased water holding capacity and cooking loss. High cooking loss is an indicator weak protein binding and plenty of fluid was discarded. The results showed that storage time had a significant effect on cooking loss, where the longer storage, the higher the cooking loss. It was because meat protein was utilized by microbes and to decrease water holding capacity. This was in accordance with Arizona et al (2011) said that the longer storage time will increase cooking loss because meat protein was utilized by microbes, so water holding capacity decreased and higher cooking loss.

\section{Tenderness}

The results showed that kecombrang leaves condition did not significantly affect meat tenderness because kecombrang did not have proteolytic enzyme that was able to improve the tenderness of meat. This results was in line with Komariah (2004) that the concentration of the antimicrobial compound additions did not significantly affect meat tenderness. Proteolytic enzyme is able to break down proteins and will improve the tenderness of meat. In addition, meat protein suffered in damage or denaturation. Denaturation will increase tenderness of meat (Hidayah, 2015).

Table 8. Average meat cooking losses of kecombrang leaves condition and different storage time.

\begin{tabular}{lcccc}
\hline Leaves condition & \multicolumn{3}{c}{ Storage time (days) } & \multirow{2}{*}{ Mean ${ }^{\text {ns }}$} \\
\cline { 2 - 4 } & 0 & 3 & 6 & $42.77 \pm 3.00$ \\
Control & $40.53 \pm 3.51$ & $41.70 \pm 5.18$ & $46.07 \pm 0.32$ & $40.02 \pm 3.67$ \\
Pasta & $35.13 \pm 7.70$ & $41.93 \pm 2.14$ & $43.00 \pm 1.15$ & $40.29 \pm 1.39$ \\
Powder & $34.97 \pm 1.55$ & $42.27 \pm 1.58$ & $43.63 \pm 0.95$ & \\
Mean & $36.88 \pm 4.25^{\mathrm{p}}$ & $41.97 \pm 2.97^{\mathrm{q}}$ & $44.24 \pm 0.80^{\mathrm{q}}$ & \\
\hline
\end{tabular}

$p, q$ Difference superscripts within row indicate significant differences $(P<0.05)$.

ns Non-significant 
Table 9. Average meat tenderness of kecombrang leaves condition and different storage time. $(\mathrm{kg} / \mathrm{cm} 2)$

\begin{tabular}{lcccc}
\hline Leaves conditions & \multicolumn{3}{c}{ Storage time(days) } & \multirow{2}{*}{ Mean $^{\text {ns }}$} \\
\cline { 2 - 4 } & 0 & 3 & 6 & \\
\hline Control & $9.07 \pm 1.78$ & $9.56 \pm 0.66$ & $9.77 \pm 1.88$ & $9.47 \pm 1.44$ \\
Pasta & $8.20 \pm 0.96$ & $8.03 \pm 0.32$ & $8.00 \pm 1.06$ & $8.08 \pm 0.78$ \\
Powder & $9.14 \pm 0.25$ & $8.13 \pm 0.99$ & $8.43 \pm 0.43$ & $8.57 \pm 0.56$ \\
Mean & $8.80 \pm 0.10$ & $8.58 \pm 0.66$ & $8.74 \pm 1.12$ & \\
\hline
\end{tabular}

ns Non-significant

The duration of storage also did not significantly affect tenderness. Tenderness of meat on day 0,3 and 6 was $8.80,8.58$ and 8.74 $\mathrm{kg} / \mathrm{cm}^{2}$, respectively on days 0,3 and 6 . It was because meat was kept at refrigerator temperature, so there was no shortening of the tendon resulting in tougher meat. It was in accordance with Prasetyo et al (2010) that the tenderness of fresh meat stored at refrigeration temperature did not experience a shortening of the tendon that may prevent tough meat.

Lawrie (2003) also reported that shortened tendon was not observed in lamb and meat stored at $4^{\circ} \mathrm{C}$ for 24 hours and evaluated for 7 days in a storage area did not show shortened tendon. However, it occurred in meat stored at freezing temperatures $\left(0\right.$ to minus $18^{\circ} \mathrm{C}$ ), so it can be concluded that meat stored at refrigerator temperatures in plastic wrap for seven days did not show damage sign and the level of tenderness is still maintained.

\section{Conclusions}

Kecombrang leaves powder was more effective in suppressing the growth of total microbes on day 0 and 3 than kecombrang leaves pasta, but showed similar results in suppressing the growth of microbes on day 6 and both of them could not improve the chemical and physical qualities of meat stored at refrigerator temperature up to 6 days. However, Kecombrang leaves pasta had higher antioxidant content than that of kecombrang leves powder.

\section{References}

Aberle ED, JC Forrest, DE Gerrard and EW Mills. 2001. Principles of Meat Science. 4th ed. Kendall / Hunt Publishing Company. Dubuque, lowa. 354 pages.

Adrizal, Suroso and WG Piliang. 2006. The system of determining the nutrient content of corn with artificial neural network based near infrared absorbance. Articles Competitive Research Grant Xiii / II / 2006 Universitas Andalas. Padang.

Arizona RE, Y Erwanto and Suryanto. 2011. The effect of the concentration of liquid smoke shell walnuts and storage of the chemical and physical quality of the meat. Journal of Animal Husbandry Bulletin 35 (1): 50-56.

Brody AL 2000. Developing New Food Product For Changing Marketplace: Development of Packaging for Product. CRC Press Inc. United States. 616 pages.

Estiasih T and Ahmadi. 2009. Food Processing Technology. Earth Literacy, Jakarta. 138 pages.

Fenita $Y$ and EOM Daniati. 2009. Effect of water pineapple (Ananas cosumus) on the quality of meat of culled laying hens. Journal of Animal Husbandry Science Indonesia. 4 (1): 43-50.

Hidayah U, UP Juswono, and CS Widodo. 2015. Effect of extracts of clove (Syzygium aromaticum) on the protein content of beef were exposed gamma radiation. Journal of UB.

Hiariey SL. 2015. Effect of extracts Atung on water content and total bacterial smoked tuna fish filet in storage at room temperature. Journal Agroforestrix. 10(2): 100-106. 
Ismail IN and RH Ahmad. 2011. The functional properties of low-fat sausages duck with the addition of coconut oil. Journal of Agro-Industry 4 (1): 222-232.

Khine KH, MM and MHA Ngwe. 2011. Some chemical analyzes and determination of antioxidant properties of neem leaf (Azadirachita Indica A. Juss). Reading University Journal. 4(1): 227-235.

Komariah, II Arief and Y Wiguna. 2004. The physical and microbial quality of beef plus ginger (Zingiber officinale roscoe) on the concentration and duration of storage is different. Media Ranch Journal. 27 (2): 46-54.

Lawrie RA. 2003. Meet Science. Translation by Aminudin Parakkasi. 2003. Fifth Edition. Indonesia University Press. Jakarta. 377 pages.

Lusivera TK. 2002. Studying the effect of heating on the lower levels of flavonoids. Essay. Faculty of Agricultural Technology, Bogor Agricultural University. Bogor.

Naufalin R. 2005. Study of the antimicrobial properties of interest kecombrang (Nicolaia horan speciosa ) against a variety of microbial pathogens and food destroyer. Dissertation. Postgraduate Institute of Agriculture Bogor. Bogor. 181 pages.

Naufalin R, SR Herastuti and Erminawati. 2010. Potential kecombrang interest as a natural preservative in tofu and fish. National Seminar Research Center for Food, Nutrition and Health. 8 to 9 October. Faculty of Agriculture, University of General Sudirman. Purwokerto.

Naufalin R. 2013. The antimicrobial activity of the formula rind kecombrang (Nicolaia horan speciosa ) as a natural food preservative. National Seminar Papers PATPI 201326 to 29 August 2013. The Faculty of Agriculture, University of General Sudirman. Purwokerto.

Pearson AM. 1987. Muscle Function and Postmortem Changes. Food and Nutrition Press Inc., Westport, Connecticut.
Pestariati. 2008. Effect of storage time at temperatures refrigator chicken meat to the total number of bacteria, Salmonella $s p$, protein content and acidity. Journal of Bioscience Degree. Airlangga University Graduate Program. Surabaya.

Prasetyo H, MC Padaga, and ME Savitri. 2013. Study of Physical and chemical quality of the beef in the market town of Malang. Journal of Animal Science and Technology Results. 8 (2): 1-8.

Rahayu WP 2000. The antimicrobial activity of galangal ( Alpinia galanga L. Swartz) Proceedings of the National Seminar on Traditional Food Yogyakarta March 16, 1999. ISBN 979-95554-18. Journal of Technology and Food Industry. 11(2): $42-48$.

Soekarto. 1985. Assessment Organoleptik for Food Industry and Agricultural Products. Bhatara Script. Jakarta. 250 pages.

Soeparno. 2015. Meat Science and Technology. Second Edition. Gadjah Mada University Press. Yogyakarta. 545 pages.

Sudarmadji S, H Bambang and Suhardi. 1997. Analysis Procedure for Foodstuff and Agriculture. Liberty. Yogyakarta. 160 pages.

Vergiyana N, Rusman and Supadmo. 2014. Microbial and chemical characteristics of chicken sausage with the addition of chitosan and red yeast rice are stored in the refrigerator. Livestock Bulletin. 38(3): 197-204.

Wahyunindiani DY, S Wijana and Sucipto. 2015. The effect of the difference in temperature and the drying time of the antioxidant activity of powdered leaves of the soursop (Annona muricata $L$.). Journal of Brawijaya University.

Yen $\mathrm{G}$ and H Chen. 1995. Antioxidant activity of various tea extract in relation to Reviews their antimutagenicity. Journal Agriculture Food Chemistry. 43 (1): 27-32. 